\title{
FENOMENA HIBRIDASI SAINS DALAM KARYA SASTRA
}

\author{
Bayu Pramono, Redhitya Wempi Ansori \\ Universitas Negeri Malang, Pramonobayu3@gmail.com \\ Universitas Negeri Malang, Redhityawempiansori@gmail.com
}

\begin{abstract}
This article discused about's current issues regarding development of Indonesian literature. The developments include many things, one of which concerns the employment of creativity in literature. Instatement of literature in this era is destined to answer the challenges of the times. Literature faced with the realities of the modern world that everything must be completely reasonable (make sense). Therefore, the employment of the literary creative process not only focuses on spices romatisme life figure "who" is so sentimental and dramatic, but the employment of current literature also involves a particular scientific field. Literature connected, combined, and mixed with science in his creative process, resulting in hybridization of science in literature. Instatement of literature involving science gives the impression that the literature in his creative process not only as "katak dalam tempurung" because it deals with the same issues. This article covers the period of scientific literature, development of scientific literature, and representations of science in literature. Literary works are analyzed to see the phenomenons of hybridization of science in literature are Dewi Lestari whit "Akar" and "Supernova", and Andrea Hirata whit "Laskar Pelangi".
\end{abstract}

Key words: latest issues of literature, devolepment of literature, science and literature hybrid.

\section{PENDAHULUAN}

Dekade ini berkembangan sastra sangatlah pesat. Sastra tidak hanya dalam lingkup internal sastra, tetapi kajian sastra mulai interdispliner. Kini sastra mulai merambah nuansa lain yang memiliki sisi yang berbeda dengan sastra, namun sisi yang berbeda tersebut dapat menambah khasanah pengkaryaan sastra menjadi berkembang dinamis. Sastra dikenal sebagai sebuah seni yang lebih menitik beratkan unsur imajinasi, kreativitas, dan tambahan pernak-pernik khusus ala sastra yang tidak ada dalam sains. Dulunya sastra dan sains seperti terdapat tembok yang kokoh yang menghalangi pertemuan dan pembauran mereka dalam satu konteks pembahasan. Secara filosofis sastra lebih menganut filsafat idealisme dan fenomenologi, sedangkan sains merupakan produk ilmiah dan lebih menganut filsafat materialisme dan juga positivistik. Hal 
tersebutlah yang membuat seolah-olah sains dan ilmu sastra bagaikan minyak dan air yang tidak dapat menyatu. Padahal, bukan tidak mungkin sastra dan sains bersinergi untuk saling melengkapi untuk membuat suatu pengkaryaan yang baru, atau melengkapi sesuatu yang dirasa kurang dari kedua disiplin ilmu tersebut.

Dikotomi sastra dan sains membuat kedua ilmu tersebut terkesan kering dan monoton. Banyak pula dijumpai sains yang terkesan kaku dan angker karena penyampaiannya yang tidak luwes. Dunia barat memperkenalkan sastra dan sains dengan menggunakan sastra sebagai metode untuk menyampaikan sains yang terkesan kaku dan angker menjadi indah dan luwes, seperti buku karya Natalie Sinclair yang berjudul Mathematic and Beuty, Joseph Carrol dengan buku Literary Darwinism, dan Janos Laslo dengan buku The Sience of Stories.

Sebagai wahana kreativitas sastra dituntut untuk mampu membuka lahan seluasseluasnya terhadap fenomena baru agar tidak terkesan seperti "katak dalam tempurung". Hibriditas merupakan lahan baru untuk mengembangkan ide, gagasan, dan kreativitas untuk suatu hal yang baru, dalam konteks ini adalah "sastra". Sastra yang kering dan absurd pada era sekarang ini dipandang sebagai sastra yang tidak menjawab tantangan zaman. Seperti ketika kita membaca puisi karya Sutardji Colzum Bahri.

Kemajuan teknologi informasi dan komunikasi membuat intelektualitas penikmat sastra berkembang, sehingga yang dibutuhkan adalah suatu kebaruan (invention). Pieterse menyinggung tentang fenomena hibridasi ${ }^{4}$ sastra dengan globalisasi atas kemodernan manusia. Paradigma Marxisme 5 juga ditengarahi sebagai tonggak awal bermunculannya ide-ide baru di kalangan idealis. Para ilmuan dan sastrawan tidak lagi berpikir tentang ilmu yang sudah ada, tetapi berpikir bagaimana ilmu itu bisa berkembang dan bisa dikawinkan dengan ilmu yang lain.

Penggabungan sastra dan sains dianggap masih tabu dan terlarang, karena penggabungan satu disiplin dengan disiplin lain disikapi oportunis dan terkesan mengadaada. Kerja sama ilmu-ilmu yang maujud (manifest) dalam penggunaan dua atau lebih teori dan metode dalam suatu bentuk kerja baik karya maupun kerja ilmiah dipandang negatif (Saryono, 2015). Namun, pada era ini pendapat tersebut dapat dipatahkan dengan adanya saling gayung-bersambutnya mengenai hibridasi atau kerja sama ilmu-ilmu tertentu. Pada era ini banyak ditemukan ilmu yang interdisipliner yang sudah sangat mapan, seperti psikolinguistik, sosiolinguistik, dibidang sastra banyak kajian interdispliner, seperti psikologi sastra, sosiologi sastra dan lain sebagainya. 
Fajar baru perkembangan ilmu monodisiplier dianggap memiliki kelemahan mendasar dan stagnansi ${ }^{7}$ karena ketidakmampuannya menghu-bungkan dengan ilmu-ilmu lain (Ratna, 2011:223). Multidipliner dan interdisipliner suatu ilmu, dalam konteks ini "sastra dan sains" dapat dipandang sebagai fajar baru bukan malah menjadi tonggak kehancuran suatu disiplin tertentu. Sastra yang dipandang sebagai bacaan hiburan dan sebagai fungsi untuk bacaan mengisi waktu luang harus ditambah juga sebagai fungsi untuk memberikan informasi, wawasan, dan sebagai penyampai nilai-nilai kemanusiaan.

Beberapa hal yang melatarbelakangi hibridasi sastra dan sains salah satunya adalah bergesernya pandangan mengenai monodisipliner menuju interdisipliner (simak Saryono, 2015). Bergesernya pendulum monodisipliner ke interdisipliner tersebut berdampak pada pengkaryaan sastra. Saryono (2015) menyatakan seberti berikut.

"Paradigma kecendurungan ilmu-ilmu umum telah mendominasi bahkan menghegemoni ilmu yang tumbuh berkembang semasa modern, dengan kata lain paralelisme tersebut menginformasikan bahwa apa yang berkembang dalam ilmu-ilmu modern pada umumnya berkembang pula pada ilmu khusus tertentu, misalnya apa yang berkembang dalam ilmu analitis atau ilmu-ilmu kealaman berkembang pula dalam ilmu bahasa dan sastra sebagai bagian ilmu humaniora atau ilmu kemanusiaan."

Pendapat di atas jika ditarik dalam fenomena yang terjadi sekarang ini memang benar adanya. Di Indonesia pada era ini mulai bermunculan sastra yang bertemakan fiksi ilmiah (science fiksi), yang merupakan tonggak hibridasi sastra dengan sains. Memang dalam dunia pengkaryaan sastra belum banyak dijumpai karya fiksi ilmiah sebanyak karya prosa fiksi yang lain, namun pada beberapa tahun belakangan ini banyak muncul karya sastra bermuatan sains seperti Supernova karya Dewi Lestari, Area $X$ yang ditulis oleh Eliza Handayani, Anaomali karya Santopay, dan karya-karya dari Andrea Hirata yang banyak bermunculan terminologi sains di dalamnya. Karya-karya sastra yang bermuatan sains tersebut mampu membuka tabir mengenai sastra yang baik. Yakni sastra yang banyak mengandung matafora dan perlu perenungan yang dalam untuk memahami bahwa sastra ternyata bisa berkembang dan bermuatan sains.

Periode Karya Sastra Bermuatan Sains

Periode munculnya fiksi ilmiah belum ada literatur yang menyebutkan secara pasti. Tradisi pengkaryaan fiksi di Eropa, khususnya di Spanyol mulai terkenal dengan munculnya novel yang berjudul Don Quixote (1605). Novel tersebut mengangkat mengenai fiksi sains yang bertemakan cerita romantis dengan bumbu-bumbu fiksi ilmiah 
dalam proses kreatifnya. Kemudian dengan adanya hal tersebut, di Perancis muncul novel yang berjudul de Contees de Fess yang merupakan sebuah cerita dongeng peri (fairy tale) (Reid, 2009:12). Dalam salah satu paparan Reid (2009: 12), menyatakan terdapat berbedaan mengenai fiksi sains pada abad pertengahan dan pada era modern. Perbedaan tersebut terletak pada interpretasi pengarang terhadap keajaiban (the interpretation of miracle). Keajaiban pada era pertengahan (medieval) lebih menitik beratkan pada operasi teknik terhadap peran Tuhan. Peran Tuhan yang dimaksud dalam bukunya Reid (2007: 13) menyatakan bahwa Tuhan memberikan keajaiban berupa kekuatan kosmologi yang begitu besar. Dari hal tersebut diturunkan banyak karya yang berangkat dari sebuah fiksi namun seolah-olah dilakukan dengan proedur ilmiah. Dari periodisasi awal karya fiksi ilmiah di Eropa tersebut banyak memengaruhi pengaryaan sastra negara-negara lain. Pada era modern fiksi ilmiah banyak ditemukan yang mengangkat mengenai teknologi yang berperan dalam pembentukkan makhluk mitologi seperti alien yang banyak ditemukan pada cerita-cerita fiksi sains modern.

Sumber lain, seperti yang dipaparkan oleh Jose Angel Garcia Landa dalam bukunya yang berjudul "Science and Literature: Some Critical Parameters" diungkapkan bahwa dalam perkembangannya sains dan sastra memiliki hubungan yang harmonis saling membantu dalam proses pengaryaan yang dinamis dengan peminjaman terma, saling tukar ide dan pengembangan ide yang lebih kompleks untuk mengaryakan sastra lebih bervariatif. Dalam kajian mengenai kritik sastra dan teori sastra Plato pernah menyebutkan dan membicarakan mengenai hubungan antara sastra dengan pengetahuan. Dengan segera Plato pada paparannya menyinggung fokus penggunaan sastra pada pendidikan sebagai fungsi etik untuk pengkajian nilai luhur. Pada masa itu Plato dengan tegas memberikan sumbangsih yang dikutip oleh Landa dan kemudian dikembangkan dalam bukunya dengan pendapatnya "the literature use for acquisition of reliable knowledge". Berdasarkan pendapat tersebut dapat diterjemahkan pada periode sastra memiliki peran sebagai pemerolehan pengetahuan yang reliabel. Artinya pada era tersebut sastra berperan menjembatani para ilmuwan yang terlalu kaku dalam penyampaian ilmu-ilmu pengetahuan yang ditelurkan dari ancangan positivistik dan materialisme, sehinggga ilmu-ilmu sosial dan ilmu sastra tidak memiliki tempat pada ranah pengkajian yang digemari pada waktu itu. Oleh sebab itu, hibridasi atau penggabungan ilmu digunakan sebagai proses untuk memeroleh pengakuan.

Periode-periode perkembangan kajian interdispliner karya sastra terus berupaya berkembang untuk memeroleh pengakuan. Sastra ingin menunjukkan diri bahwa sastra 260 | E-ISSN: 2527-8754 http:// journal.unesa.ac.id/index.php/Paramasastra 
juga berperan dalam pengembangan ilmu, dimana periode positivistik menganggap hal yang ilmiah adalah berbicara mengenai bukti nyata bukan hanya cerita-cerita yang hanya sebagai hiburan. Dalam esainya yang berjudul "The Relationship between Literature and Science in the Nineteenth Century: A Discussion of an Interdisciplinary Approach", Flohr menyampaikan bahwa secara tradisional sastra mencoba memahami mengenai suatu teks yang memiliki arti, struktur, dan digunakan sebagai media untuk berekspresi. Diskusi mengenai pendekatan interdisipliner dalam pengkajian ilmu berupaya menghubungkan sastra dan sains, yang pada fungsinya berperan dalam kemanusian (Flohr, 1998:1). Dalam proses kemanusian, sastra pada periode tertentu berperan untuk mengonstruksi nilai-nilai kemanusian dengan cara sastra yaitu bisa melalui puisi, memberikan plot atau alur cerita dalam novel yang dapat menggugah kemanusian.

Periode-periode hibridasi sastra dan sains jika disimpulkan dari proses perkembangannya di setiap periode merupakan sebuah upaya kemanusiaan yang mencoba untuk tidak membuat sekat-sekat tembok kokoh di antara berbagai bidang keilmuan. Pada setiap periode, setiap pakar atau ahli yang menulis buku yang digunakan sebagai rujukan dalam kajian mengenai periode sastra bermuatan sains tersebut mencoba membuka tabir yang samar-samar diantara sastra dan sains sebagai kajian ilmu yang memiliki peran tersendiri. Sastra yang merupakan kajian huamaniora, kajian seni, kajian budaya, dan kajian fiksi memiiliki peran sebagai proses perkembangan manusia di bidang sosial kemanusiaan. Sedangkan pada bidang sains yang merupakan kajian ilmu kealamaan, memberikan sumbangsih terhadap bidang sains yang berperan sebagai proses peradaban manusia. Di antara dua kajian tersebut pada intinya bermuara pada nilai positif dan nilai etis pada nilai-nilai kemanusiaan (humanities).

Proses Munculnya Sastra Sains di Indonesia

Awal munculnya sastra sains di Indonesia ditengarai pada awal tahun 90-an. Tokoh sastrawan yang memunculkan sastra sains pada waktu itu adalah Ayu Utami. Pada novel "Saman" dia menjelaskan tentang anatomi tubuh manusia secara detail. Bagaimana bentuk tubuh manusia digambarkan seperti apa adanya. Penggambaran tersebut dapat diamati pada dua sudut pandang yang berbeda. Karya sastra di Indonesia muncul karena globalisasi dan asas demokrasi sudah diterapkan di masyarakat. Pengarang pada era sekarang bukan lagi berasal dari kalangan mahasiswa atau sastrawan murni saja, tetapi pengarang dari bidang dan profesi yang lain bisa mengarang dengan bebas. 
Syarat dari seorang pengarang adalah menulis, dan hasil karangan yang berkualitas dan layak untuk dibaca. Hal tersebut menjadikan semua orang yang berbakat dalam menulis sebuah cerita menjadi masiv dan banyak. Di tahun 2000-an, pengarang yang terjun di bidang sastra bukan lagi pengarang yang sejatinya berniat untuk menjadi pengarang. Seperti yang diungkapkan oleh Andrea Hirata, pengarang trilogi novel "Laskar Pelangi” yang kini menjadi terkenal. Ia mengungkapkan jika niatannya dalam menulis novel tersebut karena pengalaman pribadinya semata, bukan karena ia ingin menjadi penulis yang handal. Cerita yang disajikan dalam novel-novel karangannya banyak menceritakan keadaan dan fenomena alam yang terjadi di tanah Belitong.

Munculnya sastra bernuansa sains juga ditengarahi karena adanya para pengarang yang bukan lagi dari kalangan sastrawan murni. Dengan kata lain, penulis karya sastra pada era modern saat ini bisa saja berasal dari kalangan yang berbeda jurusan. Semisal saja seorang mahasiswa jurusan fisika yang mempunyai bakat menulis sebuah karangan. Karangan tersebut bisa saja disusupi sebuah pengetahuan tentang fisika yang pengarang miliki ke dalam karangannya. Kemampuan dalam menarasikan sebuah gejala alam dan pengalaman yang didapat selama mendalami ilmu tersebut akan membuat sebuah karya sastra yang berbeda dari sebelumnya. McEwan dalam jurnalnya menyebutkan "greatness in literature is more intelligible and amenable to most of us than greatness in sciene". Hipotesis tersebut bisa diterjemahkan bahwa hampir semua manusia memiliki kemampuan dalam berkarya, khususnya dalam bidang sastra. Seorang ilmuan dan cendikiawan tentunya memiliki kemampuan dalam menulis sebuah paragraf sebuah karangan. Dari kebiasaan mereka menyusun sebuah kerangka dan karangan ilmiah tentunya mereka memiliki sisi yang lebih untuk berkreatif dan berimajinasi mengenai hal-hal yang diawang dan dipikirkan.

Hal yang mendasari terjadinya hibridasi antara karya sastra dengan sains dapat kita kaji dalam psikologi sastra. Psikologi sastra memandang proses kreatif sebuah karya sastra dapat dilihat dari kepribadian dan jiwa "si pengarangnya" ( Wiyatmi, 2011:20). Bagaimanapun juga, sebuah karya sastra bisa menjadi imajiner jika pengarannya pandai dalam mengelola daya kreatifnya. Contoh kongkrit dalam hal ini yaitu ketika kita menengok sebuah karya sastra milik A.A. Navis berjudul "Robohnya Surau Kami” yang di dalamnya mengangkat sebuah keagamaan yang dia miliki. Dalam cerita tersebut sangat kental tentang unsur religinya. Pembaca dapat memahami jika psikologi pengarang secara sengaja atau pun tidak sengaja memasukkan unsur psikologi yang dia punya. Lain halnya dengan Kuntowijaya dalam karyanya "Anjing-anjing Menyerbu 262 | E-ISSN: 2527-8754 http:// journal.unesa.ac.id/index.php/Paramasastra 
Kuburan" yang alurnya menceritakan sebuah kemistikan yang memercayai tentang kesaktian kain kafan seseorang yang meninggal pada hari jumat kliwon. Dari contoh karya sastra tersebut dapat kita pahami jika sebuah karya sastra bisa beradu-padu dengan sebuah konsep yang lain. Baik dalam segi psikologi pengarang, rutinitas pengarang, keahlian pengarang, bidang yang didalami pengarang, dan masih banyak hal yang lain yang bisa beradu-padu ke dalam karya sastra.

Pemanfaatan Sastra Sebagai Bentuk/Media Pengucapan Sains

Sastra di dunia barat dapat digunakan atau dimanfaatkan sebagai media untuk menyampaikan sains. Dalam konteks ini sastra berperan sebagai unsur yang memerindah dan menjadikan sains yang kaku menjadi lebih luwes untuk dipahami. Dalam dunia barat sastra tidak hanya dibaca sebagai bacaan biasa, tapi sastra juga bisa memengaruhi emosionalitas seorang pembacanya, di barat sastra dibaca sebagai penyemangat dalam kondisi-kondisi tertentu. Dalam beberapa film barat seperti The Fault in Our Stars dan Word and Picture dipaparkan beberapa fungsi praktis sastra, yaitu sebagai penyemangat atau media untuk memberikan dorongan semangat kepada orang yang mengidap kangker.

Sedangkan pada tindak praktis di dalam pengucapan sains banyak ditemukan dalam buku-buku, seperti Mathematic in Beuty, The Scince of Stories, dan Cognitif Semantic. Buku-buku tersebut menggunakan sastra sebagai media yang membahasakan sains dengan bahasa yang lebih indah, luwes dan tidak terkesan "horor". Tidak seperti buku-buku sains kebanyakan yang tampak dalam pembahasan serius dan tampak kaku. Hal tersebut bagi orang-orang tertentu yang lebih dominan santai, suka hal yang ringanringan dalam penyampaian, cara seperti itu tidak bisa diinternalisasikan dalam pemahamannya dengan baik.

Bagi perkembangan ilmu bahasa Indonesia, tentunya fenomena ini membawa dampak yang sangat baik. Mengapa demikian, karena pembelajaran bahasa Indonesia mempunyai model dalam membuat teks. Karya sastra yang bermuatan sains dapat dimanfaatkan sebagai media dalam pembelajaran. Bagi guru bahasa Indonesia, sastra yang memiliki nilai lebih bagi pembacanya akan menjadi kesenangan tersendiri, terutama jika digunakan sebagai bahan ajar. Kegiatan pembelajaran yang menggunakan media interaktif dapat merangsang penegetahuan siswa secara long trem memory. Salah satu metode tersebut yaitu dengan menggunakan karya sastra yang bermuatan sains. Karya sastra yang di dalam alurnya terdapat pengajaran dan pelajaran yang sesuai 
dengan mata pelajaran yang terkait akan lebih menarik bagi siswa. Siswa akan tertarik untuk membaca karya sastra tersebut. Selain itu, siswa bisa mengambil nilai-nilai yang terkandung dalam cerita tersebut. Pada pembelajaran bahasa Indonesia di Sekolah Dasar metode pemanfatan bahasa dan sastra sebagai pengucapan sains diimplementasikan melalui pembelajaran berbasis tematik. Secara konsep pembelajaran berbasis tematik ini adalah lebih menggabungkan pelajaran satu dengan pelajaran yang lain kemudian diikat dalam satu tema (Dariyo, 2013:45). Hal tersebut menunjukkan bahwa pada tataran implementasi hibridasi sastra dan sains sudah dilakukan sebagai wujud mencoba meruntuhkan tempok besar penghalang penyatuan kedua ilmu tersebut.

Pada periode positivisme atau ilmiah yang terjadi pada abad ke-19 karya seni dalam konteks ini sastra dianggap memiliki kaitan erat dengan disiplin ilmu lain seperti antrpopologi, sejarah, studi sosial empirik, bahkan sains (Ratna, 2007: 75). Kaitan erat tersebut dimulai dengan penelitian dari Fechner pada sekitar tahun (1801-1887) yang mengadakan penelitian dengan metode empiris, metode induktif, dan kuantitatif. Bahkan ia juga menggunakan instrumen labolatorium.

Fechner dalam penelitiannya mencoba mengombinasikan antara estetika dalam sastra terhadap pengaruh psikologi pembaca. Dari penelitian tersebut ditemukan bahwa secara kuantitatif sastra memiliki hubungan yang signifikan terhadap pembaca. Bertolak dari penelitian yang dilakukan Fechner banyak bermunculan tokoh-tokoh lain yang mulai tertarik dengan penelitian serupa. Tokoh lain adalah Hippolyte Taine yang melakukan penelitian tahun (1882-1893), Taine adalah seorang filsuf, sejarawan, politisi, dan kritikus Perancis yang memberikan perhatian terhadap peranan ras dan lingkungan. Taine pun mencoba untuk mengembangkan cara-cara yang bersifat ilmiah, dengan anggapan bahwa karya seni dapat diselidiki dengan metode dan teori ilmu kealaman (Ratna, 2007: 76). Muncul juga Madame De Stael seorang ahli yang menghubungkan karya sastra dengan iklim, geografis, dan lingkungan sosial. Secara konsep hal tersebut merupakan penjabaran dari realitas alamiah kemudian diturunkan dalam karya sastra yang menggunakan sebuah kerja kreatif dan imajinatif. Ratna (2007: 76) karya sastra apapun dalam proses pengkaryaan bukan hanya mengandalkan sisi imajinatif saja, melainkan dalam sastra juga terdapat cermin positif zamannya.

Keuntungan lainnya yang terkandung dalam fenomena hybridation tersebut juga dirasakan oleh pembaca yang bukan dari kalangan akademi. Seorang yang berlatar belakang "kurang mendalam dalam pendidikan" akan mendapatkan informasi baru dan ilmu baru ketika membaca karya sastra tersebut. Kejadian alam yang diceritakan runtut 264 | E-ISSN: 2527-8754 http:// journal.unesa.ac.id/index.php/Paramasastra 
berdasarkan awal kejadian, sebab-akibat, dan hasil perilaku alam membuat alur yang menarik. Seperti halnya dalam cerita tentang kejadian bagaimana terjadinya gelombang pasang Tsunami.

"Diceritakan dengan runtut tentang awal bagaimana peristiwa tersebut terjadi. Dimulai dengan adanya gempa bumi yang berskala lebih dari 7 skala richter. Berlanjut dengan surutnya air laut yang tiba-tiba, dan berdatangan ombak-ombak besar dari arah laut. Kemudia disapunya benda-benda yang seakan menghalangi datangnya ombak. Manusia, rumah, mobil, pohon, dan segala macam benda akan disapu."

Kegiatan pembelajaran bahasa Indonesia dengan kompetesi dasar teks eksplanasi, siswa bisa mengambil contoh dari alur cerita yang ada pada karya sastra tersebut.

Pertunjukkan atau pun penampilan yang berlatar sastra sains akan memberikan sumbangsih yang lebih loyal dari pada pertunjukkan yang hanya menampilkan unsur seni sastra saja. Holmes (2012) "the detail which historians of science require for the recovery of these aspects of past science is not necessarily available to scholars working on the interface between literature and science". Jika kita memahami pendapat Holmes tersebut memang benar adanya. Nantinya pada penampilan sastra tidak hanya menampilkan unsur intrinsik sastra semata, tetapi ada tambahan ilmu yang lainnya juga. Jadi, apabila karya sastra itu dikawinkan dengan bidang yang lain (sains), maka akan memberikan banyak ilmu yang ditampilkan untuk selanjutnya ditularkan, seperti sastra itu sendiri, seni, artistik, dan ilmu sains.

Konsep media sastra sebagai pengucapan sains juga memiliki manfaat lain dalam karya sastra. Sains juga merupakan sebagai media untuk mengembangkan ide dalam karya sastra dalam konteks ini genre sastra sains fiksi yang mengemas sains dalam bentuk fiksi yang yang diceritakan dengan menarik dalam sastra. Genre fiksi ilmiah merupakan sebuah ide interdispliner yang harus dikembangkan dan diapresiasi karena kajian ini membuat sastra tidak terkesan absurd dan terlalu kering dalam proses kreatifnya. Interdisplener memberikan ruang yang luas untuk mengekplorasi sastra lintas bidang dengan tetap pemperhatikan kaidah-kaidah sastra yang indah dan dinamis dengan dibumbui sains yang imliah.

Secara paradigmatis pada saat tertentu ilmu pengetahuan mencapai puncak dan akhirnya terjadi revolusi. Menurut Ratna (2011: 225) interdisipliner merupakan kajian ekstrinsik sebagai makro sastra. Dari pendapat tersebut digambarkan bahwa kajian monodipliner memang membuat ilmu objektif dan lebih empirik namun pada sisi lain 
pasti ilmu tersebut mengalami stagnansi atau jalan di tempat karena yang dikaji hal yang sama. Begitupun juga dengan proses kreatif sastra yang diangkat hanya itu-itu saja maka akan terjadi stagnansi alur cerita yang membuat sastra terkesan kering dan pada muaranya membosankan. Sastra bernuansa sains merupakan mengembangan cerita yang berlatar ilmiah, konsepnya adalah sastra harus mampu berkontribusi dalam mencerdasarkan pembacanya melalui bacaan hiburan.

Representasi Sains dalam Karya Sastra

Perkembangannya sastra di era modern ini mulai merambah unsur-unsur lain dalam proses kreatifnya, dalam konteks ini adalah sains atau ilmu eksakta. Pada prosesnya seperti yang telah dipaparkan dalam kajian sebelumnya mengenai prosesnya bagaiamana sastra dengan sains berkolaborasi untuk menghasilkan suatu ide cerita yang menarik untuk dipaparkan. Nama-nama karya sastra bermuatan sains yang muncul pada angkatan 2000-an adalah Dewi Lestari atau dikenal dengan nama populernya Dee. Novelnya yang berjudul "Supernova: Ksatria, Putri, dan Bintang Jatuh" merupakan novel yang populer, dan pembaharu dalam pengaryaan sastra Indonesia. Pembaharuan tersebut bertolak dari aliran yang masih awam yang dibawa oleh Dee ke Indonesia, yakni science fiction. Kemudian, muncul Andrea Hirata seorang penulis novel yang studi mayornya merupakan ekonomi, yang menulis beberapa novel bertajuk tretalogi yang memiliki tempat di hati masyarakat dan penikmatnya.

Pemaparan kali ini akan mengkaji dan mengulas beberapa hal unsur sains yang terdapat dalam beberapa novel tersebut, yakni "Supernova: Ksatria, Putri, dan Bintang Jatuh" karya Dee, “Akar” karya Dee, dan “Laskar Pelangi” karya Andrea Hirata. Dalam kajian ini akan berikan kutipan yang mendukung kemudian diulas unsur sains apa yang terdapat dalam kutipan tersebut.

Novel yang berjudul "Akar" Dee mencoba memaparkan unsur sains berupa biologi tumbuhan untuk mengesankan intelektualitasnya dalam gaya berceritanya.

"Bong, membangun punk scene yang tidak bisa dibilang kecil. Meski paling benci disebut ketua geng dan menganut prinsip rhizoma dalam membina jaringan, ia tetap dituakan dan dihormati seluruh scene di negeri ini karena dialah yang paling cerdas dan berwawasan"( dikutip dari novel "Akar).

Dalam kutipan tersebut dalam proses penggambaran watak tokoh yang bernama "Bong" Dee menggunakan prinsip sains dari ilmu biologi tumbuhan. Yaitu menyinggung 266 | E-ISSN: 2527-8754 http:// journal.unesa.ac.id/index.php/Paramasastra 
istilah "rhizoma" yang merupakan sebuah modifikasi dari batang tumbuhan yang tumbuhnya menjalar di bawah permukaan tanah dan dapat menghasilkan tunas dan akar baru dari ruas-ruasnya. Dari hal tersebut Dee ingin memaparkan bahwa tokoh "Bong" merupakan seorang tokoh yang sentral dalam komunitas punk scene tersebut.

Kutipan berikut ini dari novel "Akar" yang menggunakan sains di bidang kimia untuk menjelaskan suatu fenomena dalam percakapan tokoh.

"Tadi lo diantar ojek si Kinun, terus begitu turun, lo langsung merapat ke selokan. Lupa lagi? Bong menyeringai. Gigi keroposnya—konon karena terlalu banyak minum softdrink."

Dari kutipan tersebut Dee mencoba memasukkan unsur sains di bidang kimia untuk menjelaskan suatu hal terjadi pada gigi tokoh "Bong". Secara ilmiah hal tersebut terbukti benar karena softdrink merupakan minuman bersoda yang tidak baik bagi kesehatan. Hal sampingan dari kebanyakan minum soft drink tersebut secara fisik berdampak bagi gigi yang keropos karena pengaruh dari paparan zat kimia dari soda. Oleh sebab, itu Dee dalam pemaparan ceritanya memberikan konsep sains yang ilmiah untuk lebih meyakinkan.

Kutipan berikutnya menunjukkan unsur sains di bidang biologi yang terdapat dalam bagian cerita dari novel "Akar".

“........saya melihat sekeliling, ternyata selaput aneh itu ada dimana-mana, , di rambut, di muka, di tangan, di udara, di sampah lebih banyak lagi. Sampai saya sadar selaput itu adalah kawanan kuman atau apalah, mikroorganisme yang seharusnya tidak terlihat dengan mata telanjang..."

Pada kejadian tersebut seorang tokoh "aku" merasakan sebuah kejanggalan. Dia seperti berimajinasi dan pikirannya tidak menentu. Setting kejadian tersebut pada ruang makan, ketika tokoh tersebut menikmati bakpao, pikirannya berimajinasi seakan melihat banyak kuman. Seperti selaput putih yang ada di bagian luar bakpao itu ada yang bergerak-gerak. Yaitu unsur mikro organisme berupa kuman. Namun, dalam kejadian tersebut jika dilihat dari sudut pandang ilmiah memiliki kejanggalan karena diketahui mikroorganisme itu adalah organisme kecil dan tidak dapat dilihat secara mata telanjang, sehingga unsur sains yang ada di dalam penggalan cerita tersebut hanya digunakan 
sebagai bumbu-bumbu saja, tidak untuk mempertegas fenomena yang ada dalam cerita pada kutipan yang lain.

Berikut ini adalah kutipan dari novel karya Dee yang berjudul "Supernova, Ksatria, Putri dan Bintang jatuh". Unsur-unsur keilmuan juga ditemukan dalam pemaparan ceritanya, seperti dalam kutipan berikut.

“...Tiga bulan dan dua puluh satu hari berikutnya, mereka dilanda badai baru. Badai Endorfin. Hormon cinta..."

Dalam kutipan tersebut digunakan istilah "endorfin". Secara konsep, "endorfin" merupakan senyawa kimia alami yang ada di dalam tubuh. Endorfin diproduksi oleh kelenjar pitutary yang berada di bawah otak. Banyak orang menyebut endorfin merupakan narkoba alami yang ada di dalam tubuh. Jenis narkoba alami tersebut berupa morfin yang berfungsi untuk merangsang rasa senang dalam tubuh. Dalam kutipan tersebut dipertegas dengan menyebutkan hormon cinta. Secara konsep Dee sudah memegang prinsip dasar bahwa endorfin merupakan hormon yang menyangkut kesenangan, sehingga Dee menggunakan istilah tersebut untuk menguatkan makna yang menyangkut dua orang tokoh dalam novel tersebut yang sedang jatuh cinta.

Kutipan berikut menunjukkan bahwa konsep hibridasi keilmuan juga digunakan pengarang untuk menjelaskan jalinan cerita atau plot yang dipaparkan dalam kutipan novel "Supernova" berikut.

“.......Si Indo-Yahudi bersemangat tinggi yang selalu sibuk menggabung-gabungkan ilmu psikologi dengan teori-teori kosmologi ..."

Dari kutipan tersebut menunjukkan bahwa unsur-unsur keilmuan digunakan untuk menjelaskan rangkaian cerita bahkan mempertegas cerita agar lebih meyakinkan pembaca. Meskipun novel tersebut fiksi, namun terdapat unsur unsur keilmuan tertentu yang dapat memperkaya pembacanya. Selain fungsi tersebut tentunya dapat digunakan untuk mempertegas cerita yang ingin disampaikan melalui peminjaman istilah dan konsep sains. Berdasarkan kutipan tersebut menunjukkan bahwa tokoh tersebut merupakan sosok yang cerdas dan memiliki pengetahuan tinggi hal tersebut terbukti, tokoh yang ada dalam cerita memiliki sense of scientific yang mampu meramu suatu unsur keilmuan tertentu dengan keilmuan yang lain. Dari jalinan cerita yang ingin diungkapkan pengarang melalui tokoh terdapat dua maksud. Pertama, pengarang ingin menyisipkan unsur pengetahuan dari suatu cerita dalam novel, dalam konteks itu pengarang mencoba 268 | E-ISSN: 2527-8754 http:// journal.unesa.ac.id/index.php/Paramasastra 
memasukkan fungsi dulce dan utile di dalam sastra. Kedua, dari paparan tersebut pengarang ingin mempertegas cerita dan mempertegas genre novel yang konteks ini adalah novel science fiction (fiksi ilmiah).

Kutipan berikut merupakan konsep matematika, kedokteran, dan psikologi yang terdapat dalam novel "Supernova" yang dipaparkan sebagai berikut.

“....terciptanya sebuah sistem pada dasarnya diakibatkan atraktor yang terus menerus melakukan feedback atas dirinya sendiri. Proses arus balik itu kemudian menyebabkan sistem teramplifikasi, hingga tiba di titik dimana ia mengalami fluks, atau disodori pilihan untuk berubah. Fase penuh ke bimbangan itu lalu itu mencapai kulminasinya, sampai terjadilah apa yang disebut bifurkasi tonggak sejarah bagi sebuah sistem untuk berevolusi. Malam itu, terjadi fluks hebat untuk mengocokngocok solar plexus Reuben. Ia dapat merasakannya. Ia berada pada titik bifurkasi."

Kutipan tersebut menunjukkan konsep sains yang digunakan untuk untuk menggambarkan suatu kejadian dalam jalianan cerita dari tokoh Reuben. Pengarang dalam menceritakan hal tersebut menggunakan konsep sains sesuai alur dari sebuah proses kerja sains yang ilmiah. Dari terminologi yang digunakan pengarang mencoba menggabungan ilmu-ilmu sains dari bidang matematika, kedokteran, dan juga psikologi. Istilah atraktor bila digambarkan seperti ayunan pendulum yang berhenti pada satu titik. Di mana titik pendulum berhenti itulah yang biasanya oleh matematikawan disebut sebagai titik atraktor. Titik atraktor lebih tepatnya disebut region magnetis yang memiliki kekuatan yang dapat menarik suatu sistem ke dalam dirinya.

Istilah berikutnya adalah bifurkasi secara etimologis merupakan titik percabangan dua, artinya bifurkasi adalah momen yang mengkristal atau suatu kondisi dimana seseorang tidak bisa kembali ke sana atau flasback ke suatu kejadian yang pernah dialami, sehingga terjadi kekekalan. Sedangkan, solar plexus merupakan istilah yang digunakan dalam ilmu kedokteran yang berhubungan dengan syaraf. Dari hal tersebut terminologi-terminologi tersebut digunakan untuk menceritakan suatu jalinan cerita yang menarik dari suatu tokoh menggunakan prinsip ilmiah atau meniru proses kerja ilmu sains. 
Kutipan berikut diambil dari novel yang berjudul "Laskar Pelangi" karya Andrea Hirata, kutipan berikut mengandung konsep ilmu biologi tumbuhan yang dipaparkan sebagai berikut.

“.....ia seperti pilea, bunga meriam itu yang jika butiran air jatuh di atas daunnya, ia melontarkan tepung sari, semarak, spontan, mekar, dan penuh daya hidup. Di dekatnya, aku seperti ditantang mengambil ancang-ancang untuk sprint seratus meter."

Dari kutipan tersebut menggambarkan suatu plot/alur cerita menggunakan prinsip sains pada bidang biologi, lebih spesifik dibidang tumbuhan. Kutipan tersebut menceritakan tokoh Lintang yang begitu semangat karena dia bisa bersekolah dan harihari di sekolah merupakan hari-hari yang selalu di tunggunya setiap malam. Perasaan semangat tokoh Lintang digambarkan oleh pengarang menggunakan konsep sains, berupa proses penyerbukan pada tumbuhan dalam konteks ini adalah bunga. Konsep penyerbukan dalam bunga cukup rumit. Seperti bertemunya serbuk sari dan pada kepala putik. Biasanya serbuk sari masuk dari tangkai putik menuju bakal buah. Di dalam bakal buah ada bakal biji. Bakal biji berisi sel kelamin betina (sel telur). Setelah sel kelamin jantan dan sel kelamin betina bertemu terjadi pembuahan. Dalam kutipan cerita dari novel tersebut pengarang ingin menggambarkan bahwa semangat tokoh Lintang dari paparan cerita tersebut seperti proses penyerbukan pada bunga, begitu sulit namun tetap bisa dilalui dan tetap membuahkan hasil.

Kutipan berikutnya dari novel yang sama. Di mana konsep sains digunakan pengarang sebagai unsur plot/alur cerita yang dipaparkan sebagai berikut.

“.....dalam sekejap ia tenggelam di lamun kata-kata ajaib pembangkangan Galileo Galilei terhadap kosmologi Aristoteles, ia dimabuk rasa takjub gagasan gila para astronom zaman kuno yang terobsesi mengukur jarak bumi ke andromeda dan nebulanebula triangulum. Lintang menahan nafas ketika membaca bahwa gravitasi dapat membelokkan cahaya saat memelajari tentang analisis spektral yang digunakan untuk studi bintanggemintang....."

Dari kutipaan tersebut menunjukkan bahwa konsep sains dapat digambarkan melaui jalinan cerita (plot). Konsep sains dalam sastra berdasarkan paparan tersebut memberikan suatu pengetahuan tambahan kepada pembaca mengenai sains yang terkesan angker dan kaku. Kesan tersebut menjadi lunak dan menarik ketika digambarkan dalam suatu 270 | E-ISSN: 2527-8754 http:// journal.unesa.ac.id/index.php/Paramasastra 
rangkain cerita yang menarik dikemas dengan menyenangkan dalam konteks seni. Berdasarkan fungsi tersebut sastra memberikan konsep kebermanfaatannya sebagai pengaktifkan kompetensi akademik pembaca. Bukan tidak mungkin melalui sebuah cerita berunsur sains yang digambarkan pengarang dalam novel tersebut menjadi batu loncatan oleh seseorang untuk menggali informasi lebih dalam mengenai sains tersebut.

\section{PEMBAHASAN}

Perkembangan sastra sekarang ini, bukan hanya sebagai sebuah kajian tentang seni saja, melainkan sastra berkembang menjadi suatu kajian ilmu yang ilmiah. Keilmiahan sastra tersebut ditunjukkan dari berbagai macam prosedur-prosedur yang dikembangkan untuk menelaah sastra lebih mendalam dalam lebih ilmiah. Seperti yang diungkapkan Suwondo (2003:6) tujuan ilmu pengetahuan, termasuk di dalamnya studi sastra adalah untuk mencapai suatu kebenaran atau setidaknya kebenaran yang paling mendekati kebenaran. Dari pendapat tersebut, dapat ditarik suatu konsep bahwa sastra dalam kajian dan perkembangannya sebagai ilmu melalui prosedur-prosedur ilmiah mencoba menemukan kebenaran melalui sebuah cara khas sastra. Dalam kajian ilmu untuk dapat dibuktikan bahwa itu benar dan tepat harus memiliki prosedur ilmiah. Prosedur tersebut ada beberapa tahap seperti yang diungkapkan oleh Darma (dalam Suwondo, 2003:6) dalam konteks secara objektif studi sastra untuk bisa dikatakan sebagai ilmu harus melalui tahapan-tahapan yang berjenjang seperti pemahaman, penerapan, analisis, sintesis, dan evaluasi.

Ulasan mengenai prosedur keilmuan mengalami perkembangan. Hal tersebut mengakibatkan muncul konsep hibridasi atau kajian interdisipliner sastra. Kajian ini muncul dikarenakan bahwa ilmu yang monodispliner ditemukan banyak kekurangankekurangan metodologi dalam dalam pengkajiannya, hal tersebut memicu suatu kajian interdisipliner. Kekurangan metodologi yang bersifat ilmiah tersebut merupakan hal yang wajar dalam kajian sastra karena sastra selalu berkutat pada ranah seni yang cenderung dinamis, imajinatif, dan kreatif. Namun, sastra berkembang sebagai ilmu harus menyesuaikan dengan proses kerja dan prosedur ilmiah dalam konteks ilmu pengetahuan. Seperti yang diungkapkan Suwondo (2003:6) persyaratan dan langak-langkah metodologis tersebut diantaranya adalah perumusan masalah (berdasarkan fakta, bebas dari prasangka), perumusan dan pengujian hipotesis, analisis data berdasarkan teori dan metode, dan interpretasi objektif. 
Proses pengkaryaan sastra prosedur ilmiah digunakan sebagai sebuah ide penyampaian cerita. Seperti yang telah dipaparkan dan dibahas dalam temuan unsur sains dalam tiga novel (Akar, Supernova, dan Laskar Pelangi). Unsur sains yang ada dalam tiga novel tersebut ditemuakan menyebar dalam unsur intrinsik karya sastra, seperti di dalam tokoh, penokohan, tema, dan alur/plot. Seperti yang telah diketahui bahwa tema merupakan ide, gagasan, dan pandangan hidup pengarang yang melatarbelakangi penciptaan karya sastra (Fananie, 2002:84). Dari tema tersebut muncul berbagai macam ide yang berdasarkan realitas kehidupan pengarang yang diperoleh dari berbagai keresahan hidup, kebahagiaan, dan fenomena unik yang dihadapi pengarang.

Tema merupakan unsur pengikat yang penting untuk mengembangkan cerita agar lebih terarah. Jika dilihat ketiga novel yang telah dianalisis tersebut tema besarnya adalah fiksi ilmiah karena rangkaian cerita yang dikembangkan menggunakan unsur-unsur sains. Karena secara garis besar dalam menceritakan tokoh-tokoh, dialog antar tokoh berlandaskan proses ilmiah. Seperti yang telah diungkapkan Fananie (2002:84) sebagai sebuah karya imajinatif, tema dapat diungkapkan dari berbagai cara, seperti melalui dialog-dialog tokohnya atau melalui konflik-konflik yang dibangun. Oleh karena itu, tema yang baik adalah tema yang tidak diungkapkan secara langsung, melainkan pembaca karya dapat merumuskan sendiri tema apa yang diungkapkan melalui hasil bacaannya. Apabila kita menengok ketiga novel di atas yang telah dikaji berdasarkan telaah dan hasil baca merupakan novel bertema fiksi ilmiah.

Unsur ilmiah dalam novel utama dia atas, berada pada unsur penyampaian cerita atau yang disebut sebagai plot. Secara konsep plot merupakan seuatu keutuhan rangkaian peristiwa yang terdapat dalam cerita (Fananie, 2002:93). Dari beberapa novel tersebut, pemaparan peristiwa dimulai dari awal cerita menggunakan konsep-konsep sains dalam jalinan peristiwa dan penceritaannya. Seperti yang diungkapkan Fananie (2002:94) elemen plot hanyalah didasarkan pada mulainya peristiwa, berkembangnya peristiwa yang mengarah pada konflik yang memuncak, dan penyeleseian terhadap konflik. Dari pendapat tersebut jika dikaitkan pada konsep pemaparan plot dari novel-novel tersebut mengarahkan dan mengaitkan pada kajian-kajian dalam sains yang kental seperti yang telah dilakukan dalam pengkajian unsur-unsur sains dalam novel-novel tersebut pada bab sebelumnya.

Berdasarkan telaah yang telah dilakukan, dapat disimpulkan bahwa fenomena hibridasi sastra dan sains merupakan suatu perkembangan dalam dunia keilmuan yang patut diapresiasi. Kajian interdispliner tersebut dapat melengkapi hal yang kurang dari kedua 272 | E-ISSN: 2527-8754 http:// journal.unesa.ac.id/index.php/Paramasastra 
disiplin ilmu tersebut. Bagi sains, sastra dapat digunakan sebagai media penyampaian sains yang terlalu kaku dan terkesan "angker", sedangkan sastra dapat menggunakan sains sebagai media untuk mengembangkan cerita dalam setiap karya agar tidak terkesan terlalu absurd dan kering dalam proses kreatif sastra. Dari novel-novel yang telah dikaji dan dicari unsur sains terdapat dalam novel tersebut menunjukkan suatu hal baru.

\section{SIMPULAN}

Berdasarkan telaah yang telah dilakukan dapat disimpulkan bahwa fenomena hibridasi sastra dan sains merupakan suatu perkembangan dalam dunia keilmuan yang patut diapresiasi. Kajian interdispliner tersebut dapat melengkapi hal yang kurang dari kedua disiplin ilmu tersebut. Bagi sains sastra dapat digunakan sebagai media penyampaian sains yang terlalu kaku dan terkesan "angker", sedangkan sastra dapat menggunakan sains sebagai media untuk mengembangkan cerita dalam setiap karya agar tidak terkesan terlalu absurd dan kering dalam proses kreatif sastra. Dari ketiga novel yang telah dikaji dan dicari unsur sains terdapat dalam novel tersebut menunjukkan suatu hal baru.

\section{DAFTAR RUJUKAN}

Dariyo, A. 2013. Dasar-Dasar Pedagogi Modern. Jakarta: PT Indeks.

Fananie, Z. 2002. Telaah Sastra. Surakarta: Universitas Muhammadiyah Press.

Flohr, B. 1998. The Relationship between Literature and Science in the Nineteenth Century: A Discussion of an Interdisciplinary Approach. (Online). (http://www.itp.uni-hannover.de/ flohr/papers/m-res-meth1.pdf), diakses pada 29 September 2015.

Hirata, A. 2008. Laskar Pelangi. Yogyakarta: PT Bentang Pustaka

Landa, G, A, J. Tanpa Tahun. Science and Literature: Some Critical Parameters (Online),

(http://korea.ssrn.com/delivery.php?ID=0...910168064018100081110074025096 \&EXT=pdf), diakses pada 29 September 2015.

Lestari, D. 2012. Akar. Yogyakarta: PT Bentang Pustaka

Lestari, D. 2012. Supernona: Ksatria, Putri, dan Bintang Jatuh. Yogyakarta: PT Bentang Pustaka. 
Pavel, T. G. 1985. Theory and History of Literature. Minneapolis: University of Minineasota Press.

Pieterse, J. N. Tanpa Tahun. Globalization As Hybridazation. (Online), (www.uvm.edu/rsenr/rm230/Nederveen\%20Pieterse.pdf), diakses pada 29 September 2015.

Ratna, K. N. 2007. Estetika Sastra dan Budaya. Yogyakarta: Pustaka Pelajar.

Ratna, K. N. 2011. Antropologi Sastra: Peranan Unsur-Unsur Kebudayaan dalam Proses Kreatif. Yogyakarta: Pustaka Pelajar.

Reid, A. R. 2009. Women and Scince Fiction and Fantasy. New York: Green Wood Press.

Saryono, D. 2015. Kajian Bahasa, Sastra, dan Pendidikan Bahasa:

Dari Monodisipliner ke Multidisipliner. Makalah Disajikan dalam Kegiatan Prapasca Universitas Negeri Malang Tanggal 14 Agustus 2015 di Gedung Pascasarjana Universitas Negeri Malang, Malang yang diselenggarakan Program Pascasarjana UM.

Suarez, M. 2008. Fiction in Science: Philosophical Essays on Modeling and Idealization. New York: Madison Ave.

Suwondo, T. 2003. Studi Sastra: Beberapa Alternatif. Yogyakarta. PT Hanindita Graha Widya.

Wiyatmi. 2011. Psikologi Sastra: Teori dan Aplikasinya. Yogyakarta. Kanwa Publiser. 